\title{
Fashion and the Workplace: Considerations about the Attire's Role in the Organisational Environment
}

\author{
Mariana Bassi Sutter* \\ Lecturer in Marketing, The York Management School, UK
}

Submission: December 12, 2017; Published: January 26, 2018

*Corresponding author: Mariana Bassi Sutter, Lecturer in Marketing, The York Management School, UK, Email: mbsutter@gmail.com

\section{Introduction}

From the earliest times, individuals have been concerned with covering its body. Whilst modesty was one motivation, other interpretations indicate that humans covered their bodies both to protect and to adorn themselves. For centuries, clothing and ornament have been used by individuals and society as tools of non-verbal communication [1,2]. The study of clothing is therefore not limited to fashion; on the contrary, clothing can be investigated from different scientific perspectives and using the paradigms of different disciplines. Thus, it incorporates conceptual models that have their foundations in distinct branches of science [3].

Choice of attire, and in particular of what is worn to the workplace, is encompassed within the daily decision-making process of individuals. It has the potential to impact both on physical and mental comfort and may impact in the way the individual conducts his or her activities within the organisation. In the business sphere, the suit plays an important role and can influence the organisational environment. This piece seeks to explore some of the different roles of attire in society and within the work environment.

\section{The role of clothing in society}

Studies on the evolution and role of clothing in the society indicate that even in prehistory early humans were already concerned about covering their bodies. Whilst modesty may have been an aspect of this, other interpretations indicate that people covered their bodies in order to both protect and adorn themselves [4]. Wearing clothes to protect oneself from cold or physical damage in a harsh environment is associated with the survival instinct. Under the prism of adornment, the wearing of leaves and animal skins by an individual can be interpreted as a method by which individuals sought to impose power and authority on others. Themselves on others. The wearing of the teeth and claws of ferocious animals can be seen as a show of bravado and strength.

Under this interpretation, clothing and ornament have been used formillenia by both individuals and society as a tool of nonverbal communication [1,2] indicating the social position, occupation, locality, sexual availability or affiliation to a particular group [1,5]. The attire and the occasion on which it is worn allows for a superficial interpretation of the social situation of the wearer based only on physical appearance [1] The individual elements of appearance - for example a suit and accessories that complement it - are summed a whole that encompass indissociably practical and symbolic aspects [6].

According to Durand [5], people communicate their social class, age group, and sex through clothing. Above all, clothing is an instrument that instantly classifies individuals into social hierarchies [5]. Consequently, clothing establishes an interface between the human being and the natural and cultural environment, having multiple roles whose origins are complex and cannot be analysed using the prism of its functionality alone [7]. Clothing can also take the form of an indicator of moments in the individual's life as part of a group or of the life of a group as part of society [5]. As a result, we can consider the way a person dresses as a sign of their state of mind [5]

\section{From clothing to fashion}

Clothing must be fashionable [8]. However, it was only after the middle of the fourteenth century that fashion, in the strict sense, began to impose itself [9]. This was a historical moment in which a radically new type of clothing emerged, which clearly distinguished the genres: long and fair attractive for the woman, short and adjusted fitted for the men. This clothing revolution spread the foundations of modern dress and throughout the second half of the nineteenth century, fashion settled in the modern sense of the term [9].

There is no objective and universal interpretation of the fashion concept, making it difficult to define [1]. The difficulty lies in the complex logic of the phenomenon, which encompasses a multiplicity of social, individual, cultural and aesthetic life factors [9]. Fashion can thus be seen as a universal principle, being one of the elements of civilization. It has meaning beyond simple body covering and is a form of expression [10]. The 
attitudes, approaches and movements of expression of human beings are influenced by and seen through fashion, turning it into one of the great principles of transformation of societies [10].

The etymological root of the word fashion was inserted in the Italian language around 1650 and is derived from the Latin mos, whose meaning includes: use, custom, habit, tradition, morality, manners, rule, type and law [1]. According to Cavalheiro [7], fashion is a unique and complex phenomenon with social, psychological and behavioural references. Reflection on this theme allows several readings, which help to understand the growth and the behaviour of humanity, from the simple analysis of its evolution [7]. Rech [11] shares [7] thoughts and notes that fashion encompasses sociological, psychological and inherent changes in religion, architecture music, the visual arts, literature, politics, decoration, philosophical perspective and clothing.

To Freyre [12] fashion is the use, habit or style that is generally accepted, changeable over time and results from likes, whims, concepts, or influences of the environment. Freyre [12] adds that fashion is a social or cultural phenomenon, variably coercive, that demands periodic style change, and whose vitality

Table 1: Concepts of costume/fashion/clothing under various optics.

\begin{tabular}{|c|c|}
\hline Concept & Source \\
\hline Body protection & Braga (2004) [4] \\
\hline Image/aesthetic construction (2004) [4]
\end{tabular}

\section{Attire and communication in the organisation}

Both in their organisational and personal lives, people use four ways of communication: verbal, nonverbal, symbolic and paralinguistic [13]. Using the verbal form, the individual communicates through speech or writing, this being the most frequent and familiar form of communication [13]. In the organisation, an example of verbal/oral communication is instruction or direction from a manager, while the memorandum is an example of verbal/written communication [13].

The non-verbal form of communication is rather subtle and ambiguous and can be represented by body posture or gesture [13]. Symbolic communication encompasses the place where the individual lives, the type of clothing he wears, and the decor of the office, for example. Finally, the paralinguistic communication arises from the need to conquer or maintain, for a certain time, a certain social position. Therefore, fashion is considered one of the objects of reflection of semiology, which consists of any system of symbols and signs mediated by verbal or non-verbal language [2]. It means that fashion rises far above the concept of clothing that protects the body or props that embellish man in his daily life. Fashion is part of people's daily existence, translating personal identities and states of mind.

Fashion is, therefore, more than the mere idea of the costume. In essence, it is a language composed of clothes, footwear, accessories and purses, which have their own meaning and when being coordinated result in the 'look', that is, the external aspect of the individual, a system that brings together the elements within the discourse of clothing [2]. In other words, individuals express and communicate their identity to other people through their appearance [2]. Moreover, an individual can produce an image that is not his or her natural one but is one which he/ she adopts in order to be accepted into a group [2,5]. Table 1 summarizes the main notes on the costume, fashion and clothing identified in the literature. is characterized by the tone of voice, the rhythm with which the individual speaks and the pauses in the discourse, giving special meaning to the communication. For Casado [13] the costume adopted represents a form of symbolic communication used by the individual. Martins \& Pinto [14] also interpret clothing as a communication tool. For these authors, the 'dressing' factor, along with others contributes to the construction of what the authors call a visual and sound identification system.

Therefore, clothing is a communication tool used within and by organisations. This is reinforced by the marketing service literature, which states that one way to convey the brand identity is by making use of physical evidence. The employees' attire is part the physical evidence and is heavily used by services firms to communicate the brand identity. For example, many service industries such as mail, transportation services (train, airline 
and bus companies) and restaurants have uniforms or other dress codes that evidence the role of attire in communicating the brand identity.

\section{The contribution of attire in the formation of organisational culture}

Schein [15] developed a concept of work as comprising several dimensions and elaborated a concept of culture through a dynamic model in which culture is learned, transmitted and changed. This author presented three different levels by which the culture of an organisation can be apprehended, namely the level of visible artifacts, level of shared values and level of basic assumptions.

Visible artifacts are easy to perceive but difficult to interpret. Examples include organisational layout structure, behaviour and dress of people, beliefs expressed in documents, rituals and organisational myths [16]. Under this interpretation, the clothing of people in the organisational environment assists individuals in apprehending organisational culture. Moreover, the clothing in the organisational environment can be used as a demarcation of the power space element through the formal dress of the managers [17].

Aligned with the service literature, Yurchisin \& Damhorst [18] state that the clothing of the professionals in an organisation helps to form the image of the company. That is, these authors believe that in addition to the identity aspects of the professional, their appearance can also indicate the identity of the organisation.

\section{Attire and personal image in the organisation}

The image that a person builds throughout his or her professional life is directly related to his or her behaviour in the work environment. Employees purposely adopt work attire and specific clothing items that express the traits they align to, such as conservatism and authority and that can be associated not only with clothing but also with their roles at work [19].

As outlined above, the way people dress is a recognised language that propagates meanings [20]. Thus, it is important that individuals are aware that their attire can be interpreted as text and that what they wear will communicate meaning to [20]. Consequently, for organisations, it is important that the clothing style used by employees (in the work environment) is coherent with the individual's function, and helps to compose the image that is expected of individuals [21].

In addition, clothing helps the wearer to become a successful executive, helping the individual's sense of confidence [21]. Peluchette \& Karl's [22] study of MBA students found that wearing formal business clothes (suits) increased their sense of being trusted and competent as well as their feeling of being in a position of authority. In contrast, the wearing of casual clothes made participants feel friendlier but less productive in a work environment [22]. However, in the absence of a written dress code, individuals would do well to observe what others around them are wearing, irrespective of their own preferences - whilst some rules in the company are clear; others are not formalized [23].

Not only the style but the colour of clothing is an issue. In the organisational context, colour has the potential to be a powerful differentiator, with colour considered a language of extreme importance in the elaboration of the clothing texts [20]. However, little is known about the use of colours in clothing and the use of colours that do not conform to the norm specifically in the workplace setting [20].

\section{Final considerations}

After understanding the role of the attire in the routine of the individual and extending this into the work environment, it was verified that, in the business sphere, attire is seen as a communication tool. This tool is based in two principal concepts: 1) the individual communicating with others in his/ her surroundings, considered by Casado [13] as a symbolic form of communication, and 2) the individual representing the company and communicating with its clients by means of the visual standard that includes the suit that uses in the organisation [14], thus composing the company image [18]. In addition to communication, clothing can also be considered as a visible artefact [15] or physical evidence, representing a tool in the process of apprehending organisational culture [16] and conveying it to the market.

In the workplace, the attire helps him/her to express his/her beliefs in certain traits (such as conservatism, authority) which can also be associated with clothing items and, above all, his/her work roles [19]. According to the findings of Peluchette \& Karl [22], the use of formal business clothing increases the sense of confidence and competence on the part of respondents, as well as increasing their perception of authority in the environment. The importance of the attire in the business sphere is also verified, with attire both supporting the communication strategy of the organisation within the market, as well reflecting how the individual understands or seeks to position him or herself in the market and or environment in which he/she works [24].

\section{References}

1. Armoni A (2007) In: Cobra M Marketing and Fashion. First (Edn). São Paulo: Senac, Brazil.

2. Stefani PDS (2005) Moda e comunicação: a indumentária como forma de expressão. Monografia apresentada à Faculdade de Comunicação Social da Universidade Federal de Juiz de Fora.

3. Hansen KT (2004) The World in Dress: Anthropological Perspectives on Clothing, Fashion and Culture. Annual Review of Anthropology 33: 369-392.

4. Braga J (2004) História da Moda: uma narrativa. São Paulo: Anhembi Morumbi, Brazil.

5. Durand JC (1988) Moda, Luxo e Economia. São Paulo. Babel Cultural. 
6. Nacif MCV (2007) 0 vestuário como princípio de leitura do mundo. XXIV SIMPÓSIO NACIONAL DE HISTÓRIA, Associação Nacional de História - ANPUH.

7. Cavalheiro W (2001) In: Castilho $\mathrm{K}$ and Garcia $\mathrm{Cl}$ (orgs). Moda Brasilfragmentos de um vestir tropical. São Paulo: Anhembi Morumbi, Brazil.

8. Veblen TB (1983) A teoria da classe ociosa: um estudo econômico das instituições. São Paulo: Abril Cultural.

9. Lipovetsky G (2009) O império do efêmero: a moda e seu destino nas sociedades modernas. São Paulo: Companhia das Letras.

10. Konig R (1969) Sociologie de La mode. Paris: Petitebibliothèque Payot.

11. Rech SR (2002) Moda: por um fio de qualidade. Florianópolis: UDESC.

12. Freyre G (2009) Modos de Homem e Modas de Mulher (2 edn). São Paulo: Global.

13. Casado T (2002) O Papel da Comunicação Interpessoal. In.: Vários autores. As Pessoas na Organização. São Paulo: Editora Gente.

14. Martins ML, Pinto Manuel (Orgs.) (2007) Comunicação e Cidadania - Actas do 50 Congresso da Associação Portuguesa de Ciências da Comunicação. 6 - 8 Setembro 2007, Braga: Centro de Estudos de Comunicação e Sociedade Universidade do Minho, Portugal.

15. Schein EH (1990) Organizational culture. American Psychological Association 45(2): 109
16. Fleury MTL, Sampaio J dos R (2002) Uma discussão sobre cultura organizacional. In: Vários autores. As Pessoas na Organização. São Paulo: Editora Gente.

17. Paiva WP, Sampaio J dos R (2003) Cultura organizacional no setor de higiene e beleza: um estudo de caso. REAd - Edição 35(9): 5.

18. Yurchisin J, Damhorst ML (2009) An investigation of salesperson appearance and organizational identification. Journal of Fashion Marketing and Management 13(3): 458-470.

19. Rafaeli A, Dutton J (1997) Navigating by attire: the use of dress by female administrative employees. Academy of Management Journal 40(1): 9-45.

20. Schemes C, Araujo DC, Andrade DF (2009) A vestimenta masculina, cores e apropriações. Cultura Visual 1(12): 11-26.

21. Castro I de (2002) A moda no trabalho. São Paulo: Editora Panda.

22. Peluchette JV, Karl K (2007) The impact of workplace attire on employee self-perceptions. Human Resource Development Quarterly 18(3): 345-60.

23. Kalil G (2004) Chi[érrimo]: moda e etiqueta em novo regime. 3rd Edn. São Paulo: Códex, Brazil.

24. Barthes R (1979) Sistema da moda. São Paulo, Nacional (Eds.) Da Universidade de São Paulo, USA.

\begin{tabular}{|l|}
\hline \multicolumn{1}{|c|}{ Your next submission with Juniper Publishers } \\
will reach you the below assets \\
- Quality Editorial service \\
- Swift Peer Review \\
- Reprints availability \\
- E-prints Service \\
- Manuscript Podcast for convenient understanding \\
- Global attainment for your research \\
- Manuscript accessibility in different formats \\
( Pdf, E-pub, Full Text, Audio) \\
- Unceasing customer service \\
Track the below URL for one-step submission \\
https://juniperpublishers.com/online-submission.php \\
\hline
\end{tabular}

